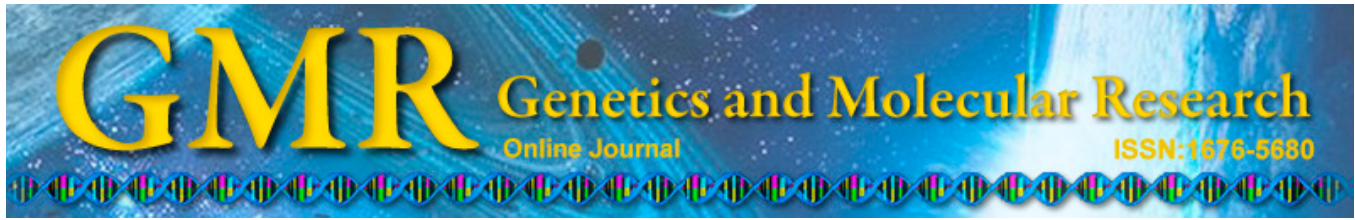

\title{
Predictive value of vascular endothelial growth factor polymorphisms on the risk of renal cell carcinomas
}

\author{
W. Xian, H. Zheng and W.J. Wu
}

The Third Affiliated Hospital of Xinxiang Medical University, Xinxiang, China

Corresponding author: X. Wei

E-mail: xianwei555@126.com

Genet. Mol. Res. 14 (3): 7634-7642 (2015)

Received August 19, 2014

Accepted January 22, 2015

Published July 13, 2015

DOI http://dx.doi.org/10.4238/2015.July.13.8

ABSTRACT. We conducted a case-control study in a Chinese
population to assess whether 5 common single-nucleotide polymor-
phisms in the vascular endothelial growth factor gene ( $V E G F$ ) affect
the risk of renal cell carcinoma (RCC). The study population in-
cluded $266 \mathrm{RCC}$ patients who were newly diagnosed and histologi-
cally confirmed to have RCC as well as 532 cancer-free controls.
Genotyping of $V E G F-2578 \mathrm{C} / \mathrm{A},-1156 \mathrm{G} / \mathrm{A},+1612 \mathrm{G} / \mathrm{A},+936 \mathrm{C} / \mathrm{T}$,
and $-634 \mathrm{G} / \mathrm{C}$ was conducted by polymerase chain reaction-restric-
tion fragment length polymorphism. RCC patients were more likely
to have higher body mass index, and have a habit of tobacco smok-
ing as well as suffer from diabetes. Conditional logistic regression
analyses showed that individuals with the AA genotype and A allele
of $-2578 \mathrm{C} / \mathrm{A}$ significantly increased the risk of RCC when compared
with the CC genotype. Individuals carrying the CT and TT geno-
types of $+936 \mathrm{C} / \mathrm{T}$ were correlated with an increased risk of RCC
compared to the CC genotype. The T allele of $+936 \mathrm{C} / \mathrm{T}$ was associ- 
ated with an increased risk of RCC. The $-2578 \mathrm{C} / \mathrm{A}$ and $+936 \mathrm{C} / \mathrm{T}$ polymorphisms in the $V E G F$ gene may play a role in the etiology of RCC.

Key words: Polymorphism; Renal cell carcinomas; Vascular endothelial growth factor

\section{INTRODUCTION}

Renal cell carcinoma (RCC) is a serious malignant tumor and the 3 rd leading cause of death in genitourinary malignant tumor cases, accounting for 2-3\% of all cancers (Jemal et al., 2009). It is estimated that the annual incidence of RCC is 37.7 men and 16.6 women per $10^{5}$ individuals in Chinese population (Yang et al., 2005).

It is well-known that development of RCC is a complex, multistep, and multifactorial process, and involves multiple environmental and genetic factors (McLaughlin et al., 1995; Bergström et al., 2001; Bjørge et al., 2004; Hunt et al., 2005; Bellocco et al., 2012). Previous studies showed that cigarette smoking, alcohol drinking, obesity, a history of hypertension, occupational exposures, and physical activity as well as family history of cancer play important roles in RCC development (McLaughlin et al., 1995; Bergström et al., 2001; Bjørge et al., 2004; Hunt et al., 2005; Bellocco et al., 2012).

Previous studies have shown that cancer stem cells can play a key role in causing tumors (McLaughlin et al., 1995; Mu et al., 2014). With developments in molecular biology, many studies have reported that numerous genetic factors are involved in the development of RCC, such as glutathione $S$-transferases, C-X-C chemokine receptor type 4, miR-34b/c, and leptin receptor genes (Cai et al., 2013; Mu et al., 2014; Zhang et al., 2014; Jia et al., 2014).

Vascular endothelial growth factor (VEGF) is a common pro-angiogenic growth factor and it is one of the most potent endothelial cell mitogens (Motzer et al., 2007; Patard et al., 2008). Stimulation of VEGF under hypoxic conditions is involved in prolonging the lifetime of malignant cells, which play a critical role in tumor growth and invasion and the development of metastases of malignant tumor. It is well-known that single-nucleotide polymorphisms (SNPs) in VEGF can affect the expression of this gene. Previous studies showed that $-2578 \mathrm{C} / \mathrm{A},-1156 \mathrm{G} / \mathrm{A},+1612 \mathrm{G} / \mathrm{A},+936 \mathrm{C} / \mathrm{T}$, and $-634 \mathrm{G} / \mathrm{C}$ are 5 common SNPs in $V E G F$, and they are reported to play a role in VEGF protein synthesis (Maeda et al., 2013).

Several previous studies reported that polymorphisms in VEGF play an important role in the development of several kinds of cancers such as bladder cancer, breast cancer, lung cancer, and renal cell carcinoma (Ajaz et al., 2011; Maeda et al., 2013; Kapahi et al., 2014; Yang et al., 2014). However, few studies have examined the association between $V E G F$ polymorphisms and RCC risk, and the results are inconsistent (Zhang et al., 2013; Zhong et al., 2014). A recent meta-analysis revealed no association between VEGF polymorphisms and RCC risk because of limitations of the studies (Zhang et al., 2013).

Therefore, we conducted a case-control study in a Chinese population and assessed whether the 5 common SNPs affect RCC risk. 


\section{MATERIAL AND METHODS}

\section{Study population}

A hospital-based case-control design was used in this study. All patients were histologically confirmed to have RCC at the Third Affiliated Hospital of Xinxiang Medical University between January 2011 and January 2013. The study population consisted of 266 RCC patients who were newly diagnosed and histologically confirmed to have RCC. The 532 cancer-free controls were randomly recruited from a pool of individuals who came to receive a health check-up in the health check-up center of the same hospital, and the control subjects were free from any cancer, and 2 healthy control subjects were matched to 1 case by gender and age.

All cases and control subjects signed an informed consent form before participating in this study, and the protocol of this study was approved by the institutional Ethics Committee of the Third Affiliated Hospital of Xinxiang Medical University.

\section{Data collection}

We collected data regarding the demographic and clinical characteristics from a selfdesigned questionnaire or medical records, including gender, age, body mass index (BMI), smoking status, diabetes status, histology, metastasis, and tumor stage.

\section{Blood samples and genotyping}

Case and control subjects were asked to provide a $5-\mathrm{mL}$ blood sample, and $0.5 \mathrm{mg} /$ $\mathrm{mL}$ ethyelenediaminetetraacetic acid was used as an anticoagulant and samples were stored at $-70^{\circ} \mathrm{C}$ until use. Genomic DNA was isolated from peripheral blood using the TIANamp Blood DNA Kit (Tiangen, Beijing, China) according to the manufacturer instructions. Five SNPs of the $V E G F$ gene were detected by polymerase chain reaction-restriction fragment length polymorphism according to manufacturer instructions, including $V E G F-2578 \mathrm{C} / \mathrm{A},-1156 \mathrm{G} / \mathrm{A}$, $+1612 \mathrm{G} / \mathrm{A},+936 \mathrm{C} / \mathrm{T}$, and $-634 \mathrm{G} / \mathrm{C}$.

The primers and probes used for $-2578 \mathrm{C} / \mathrm{A},-1156 \mathrm{G} / \mathrm{A},+1612 \mathrm{G} / \mathrm{A},+936 \mathrm{C} / \mathrm{T}$, and $-634 \mathrm{G} / \mathrm{C}$ in the $V E G F$ gene were designed using the Sequenom Assay Design 3.1 software (Sequenom, San Diego, CA, USA). The amplification program consisted of: preliminary denaturation at $95^{\circ} \mathrm{C}$ for $10 \mathrm{~min}$, followed by 35 cycles of denaturation at $95^{\circ} \mathrm{C}$ for $30 \mathrm{~s}, 62^{\circ} \mathrm{C}$ for $30 \mathrm{~s}$, and $72^{\circ} \mathrm{C}$ for $30 \mathrm{~s}$, and a final extension at $72^{\circ} \mathrm{C}$ for $10 \mathrm{~min}$. We also randomly selected $5 \%$ of the cases and control subjects to repeat genotyping of the 5 SNPs, and the results confirmed the previous results.

\section{Statistical analysis}

All statistical analyses were conducted using the STATA version 9.0 statistical 
software. Continuous and categorical variables are reported as means $\pm \mathrm{SD}$ and $\mathrm{N}(\%)$ of subjects and analyzed by the Student $t$-test. Categorical variables are reported as frequencies and percentage of study participants and analyzed by the $\chi^{2}$-test, respectively. The Hardy-Weinberg equilibrium of $V E G F-2578 \mathrm{C} / \mathrm{A},-1156 \mathrm{G} / \mathrm{A},+1612 \mathrm{G} / \mathrm{A},+936 \mathrm{C} / \mathrm{T}$, and $-634 \mathrm{G} / \mathrm{C}$ genotype frequencies between groups in control subjects were compared by the $\chi^{2}$-test. Differences in demographic and clinical factors between groups were compared by the $\chi^{2}$-test. Unconditional logistic regression was conducted to assess the effects of $V E G F-2578 \mathrm{C} / \mathrm{A},-1156 \mathrm{G} / \mathrm{A},+1612 \mathrm{G} / \mathrm{A},+936 \mathrm{C} / \mathrm{T}$, and $-634 \mathrm{G} / \mathrm{C}$ on the risk of $\mathrm{RCC}$. The results are reported as odds ratio (OR) and their corresponding $95 \%$ confidence intervals (CIs). All $\mathrm{P}$ values were 2 -sided, and a $\mathrm{P}$ value was regarded as statistically significant when it was less than 0.05 .

\section{RESULTS}

There were 87 females and 179 males in the RCC case group, while there were 174 females and 358 males in the control group (Table 1). The mean age of cases and control subjects were $60.4 \pm 11.4$ and $59.2 \pm 10.6$ years, respectively. RCC patients were more likely to have a higher BMI and have a habit of tobacco smoking as well as suffer from diabetes.

Among the RCC patients, 217 patients (81.6\%) had clear cell RCC and $12(4.5 \%)$ had papillary RCC. Fifty-seven patients (21.4\%) showed metastasis, $182(68.4 \%)$ were at stage I-II, and $84(31.6 \%)$ were at III-IV.

The genotype distributions of $-2578 \mathrm{C} / \mathrm{A},-1156 \mathrm{G} / \mathrm{A},+1612 \mathrm{G} / \mathrm{A},+936 \mathrm{C} / \mathrm{T}$, and $-634 \mathrm{G} /$ $\mathrm{C}$ in RCC cases and control subjects are shown in Table 2 . We found that the genotype distributions of $-2578 \mathrm{C} / \mathrm{A},-1156 \mathrm{G} / \mathrm{A},+1612 \mathrm{G} / \mathrm{A},+936 \mathrm{C} / \mathrm{T}$, and $-634 \mathrm{G} / \mathrm{C}$ were in Hardy-Weinberg equilibrium in the control subjects. Conditional logistic regression analyses showed that individuals with the AA genotype of $-2578 \mathrm{C} / \mathrm{A}$ significantly increased the risk of RCC when compared with the $\mathrm{CC}$ genotype, with $\mathrm{OR}(95 \% \mathrm{CI})$ of 1.84 (1.15-2.93). Moreover, the A allele of $-2578 \mathrm{C} / \mathrm{A}$ was associated with a significantly higher risk of RCC compared to the $\mathrm{C}$ allele $(\mathrm{OR}=1.37,95 \% \mathrm{CI}=1.09-1.70)$.

Individuals carrying the $\mathrm{CT}$ and TT genotype of $+936 \mathrm{C} / \mathrm{T}$ were correlated with an increased risk of RCC compared to the CC genotype, with ORs (95\% CI) of $1.51(1.05-2.17)$ and $1.93(1.25-2.97)$, respectively. The $\mathrm{T}$ allele of $+936 \mathrm{C} / \mathrm{T}$ was associated with an increased risk of $\mathrm{RCC}(\mathrm{OR}=1.43,95 \% \mathrm{CI}=1.15-1.77)$. However, we found no significant role of $-1156 \mathrm{G} / \mathrm{A}$, $+1612 \mathrm{G} / \mathrm{A}$, and $-634 \mathrm{G} / \mathrm{C}$ on the risk of RCC.

Stratification analysis on the association between SNPs of VEGF and demographic characteristics in RCC showed that the AA genotype of -2578C/A was associated with an increased risk of RCC in females, as well as those with higher age, higher BMI, and nondiabetes status (Table 3). Moreover, we found that the GG genotype of +936C/T was associated with a higher risk of RCC in females, as well as those with higher BMI, a smoking habit, and non-diabetes status. The GC genotype of $+936 \mathrm{C} / \mathrm{T}$ was correlated with an increased risk of RCC in those with higher BMI and a smoking habit. Based on interaction analysis, we only found a significant interaction between the $-2578 \mathrm{C} / \mathrm{A}$ and $+936 \mathrm{C} / \mathrm{T}$ polymorphisms and smoking status on the risk of RCC (P for interaction were 0.008 ). 
Table 1. Demographic and clinical variables among RCC cases and controls.

\begin{tabular}{|c|c|c|c|c|c|c|}
\hline Variables & RCC cases & $\%$ & Controls & $\%$ & Student $t$-text or $\chi^{2}$-test & $P$ value \\
\hline \multicolumn{7}{|l|}{$\overline{\text { Age }}$} \\
\hline Mean age & $60.4 \pm 11.4$ & & $59.2 \pm 10.6$ & & 1.47 & 0.07 \\
\hline$<60$ & 129 & 48.5 & 280 & 52.6 & & \\
\hline$\geq 60$ & 137 & 51.5 & 252 & 47.4 & 1.21 & 0.27 \\
\hline \multicolumn{7}{|l|}{ Gender } \\
\hline Female & 87 & 32.7 & 174 & 32.7 & & \\
\hline Male & 179 & 67.3 & 358 & 67.3 & 0.00 & 1.00 \\
\hline BMI $\left(\mathrm{kg} / \mathrm{m}^{2}\right)$ & $24.3 \pm 7.4$ & & $22.4 \pm 8.2$ & & 3.19 & 0.0008 \\
\hline$<24$ & 116 & 43.6 & 395 & 74.2 & & \\
\hline$\geq 24$ & 150 & 56.4 & 137 & 25.8 & 72.28 & $<0.001$ \\
\hline \multicolumn{7}{|c|}{ Smoking status } \\
\hline Ever & 113 & 42.5 & 167 & 31.4 & & \\
\hline Never & 153 & 57.5 & 365 & 68.6 & 9.58 & 0.002 \\
\hline \multicolumn{7}{|c|}{ Diabetes status } \\
\hline No & 231 & 86.8 & 510 & 95.9 & & \\
\hline Yes & 35 & 13.2 & 22 & 4.1 & 21.76 & $<0.001$ \\
\hline \multicolumn{7}{|l|}{ Histology } \\
\hline Clear cell & 217 & 81.6 & & & & \\
\hline Papillary & 12 & 4.5 & & & & \\
\hline Other & 37 & 13.9 & & & & \\
\hline \multicolumn{7}{|l|}{ Metastasis } \\
\hline No & 209 & 78.6 & & & & \\
\hline Yes & 57 & 21.4 & & & & \\
\hline \multicolumn{7}{|l|}{ Tumor stage } \\
\hline I-II & 182 & 68.4 & & & & \\
\hline III-IV & 84 & 31.6 & & & & \\
\hline
\end{tabular}

Table 2. Genotype distribution of 5 SNPs in the $V E G F$ gene between cases and controls.

\begin{tabular}{|c|c|c|c|c|c|c|c|c|}
\hline VEGF & Genotype & $\begin{array}{l}\text { Osteosarcoma } \\
\text { group }(\mathrm{N}=266)\end{array}$ & $\%$ & $\begin{array}{l}\text { Control group } \\
\qquad(\mathrm{N}=532)\end{array}$ & $\%$ & HWE & OR $(95 \% \mathrm{CI})^{1}$ & $P$ value \\
\hline \multirow[t]{3}{*}{$-2578 \mathrm{C} / \mathrm{A}$} & $\mathrm{CC}$ & 99 & 37.2 & 243 & 45.7 & & 1.0 (Ref.) & - \\
\hline & $\mathrm{CA}$ & 119 & 44.7 & 225 & 42.3 & & $1.30(0.93-1.82)$ & 0.11 \\
\hline & $\mathrm{AA}$ & 48 & 18.0 & 64 & 12.0 & 0.29 & $1.84(1.15-2.93)$ & 0.006 \\
\hline \multirow[t]{2}{*}{ Allele } & $\mathrm{C}$ & 317 & 59.6 & 711 & 66.8 & & 1.0 (Ref.) & - \\
\hline & A & 215 & 40.4 & 353 & 33.2 & & $1.37(1.09-1.70)$ & 0.004 \\
\hline \multirow[t]{3}{*}{$-1156 \mathrm{G} / \mathrm{A}$} & AA & 115 & 43.2 & 232 & 43.6 & & 1.0 (Ref.) & - \\
\hline & $\mathrm{AG}$ & 112 & 42.1 & 220 & 41.4 & & $1.03(0.74-1.43)$ & 0.87 \\
\hline & GG & 39 & 14.7 & 80 & 15.0 & 0.18 & $0.87(0.55-1.38)$ & 0.55 \\
\hline \multirow[t]{2}{*}{ Allele } & A & 342 & 64.3 & 684 & 64.4 & & 1.0 (Ref.) & - \\
\hline & $\mathrm{G}$ & 190 & 35.7 & 380 & 37.6 & & $0.95(0.76-1.19)$ & 0.64 \\
\hline \multirow[t]{3}{*}{$+1612 \mathrm{G} / \mathrm{A}$} & $\mathrm{CC}$ & 113 & 42.5 & 248 & 46.6 & & 1.0 (Ref.) & - \\
\hline & $\mathrm{CT}$ & 123 & 46.2 & 243 & 45.7 & & $1.11(0.80-1.53)$ & 0.51 \\
\hline & TT & 30 & 11.3 & 41 & 7.7 & 0.08 & $1.61(0.92-2.78)$ & 0.07 \\
\hline \multirow[t]{2}{*}{ Allele } & $\mathrm{C}$ & 349 & 65.6 & 739 & 69.5 & & 1.0 (Ref.) & - \\
\hline & $\mathrm{T}$ & 183 & 34.4 & 325 & 30.5 & & $1.19(0.95-1.50)$ & 0.12 \\
\hline \multirow[t]{3}{*}{$-634 \mathrm{G} / \mathrm{C}$} & $\mathrm{CC}$ & 104 & 39.1 & 227 & 42.7 & & 1.0 (Ref.) & - \\
\hline & CG & 132 & 49.6 & 256 & 48.1 & & $1.13(0.81-1.56)$ & 0.46 \\
\hline & GG & 30 & 11.3 & 49 & 9.2 & 0.06 & $1.34(0.77-2.29)$ & 0.26 \\
\hline \multirow[t]{2}{*}{ Allele } & $\mathrm{C}$ & 340 & 63.9 & 710 & 66.7 & & 1.0 (Ref.) & - \\
\hline & $\mathrm{G}$ & 192 & 36.1 & 354 & 33.3 & & $1.13(0.90-1.42)$ & 0.26 \\
\hline \multirow[t]{3}{*}{$+936 \mathrm{C} / \mathrm{T}$} & $\mathrm{CC}$ & 70 & 26.3 & 196 & 36.8 & & 1.0 (Ref.) & - \\
\hline & $\mathrm{CT}$ & 127 & 47.7 & 236 & 44.4 & & $1.51(1.05-2.17)$ & 0.02 \\
\hline & TT & 69 & 25.9 & 100 & 18.8 & 0.06 & $1.93(1.25-2.97)$ & 0.002 \\
\hline \multirow[t]{2}{*}{ Allele } & $\mathrm{C}$ & 267 & 50.2 & 628 & 59.0 & & 1.0 (Ref.) & - \\
\hline & $\mathrm{T}$ & 265 & 49.8 & 436 & 41.0 & & $1.43(1.15-1.77)$ & 0.001 \\
\hline
\end{tabular}

HWE: Hardy-Weinberg equilibrium. ${ }^{1}$ Adjusted for age, gender, BMI, smoking status, and diabetes. 


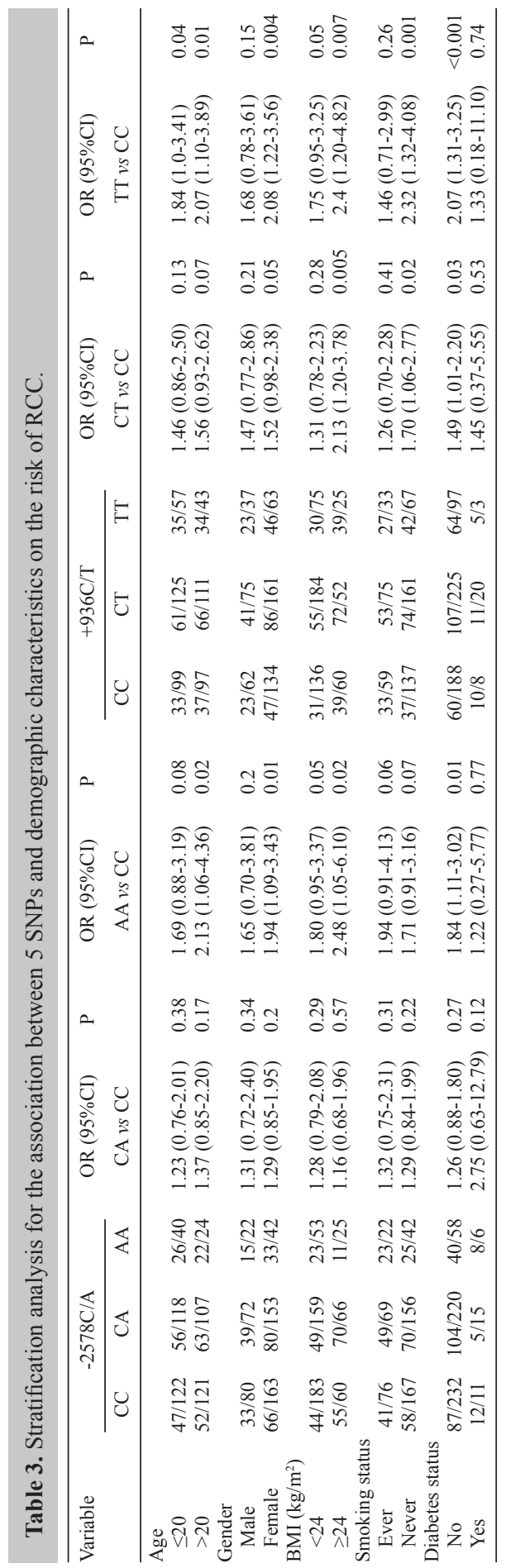




\section{DISCUSSION}

Angiogenesis is a key factor in the development of many malignant tumors. VEGF expression can play a role in regulating angiogenesis is involved in promoting endothelial cell proliferation and regulating the extracellular matrix in the blood vessels (Roy et al., 2006; Kushner and Bautch, 2013). Several functional SNPs in the VEGF gene can alter the expression levels of VEGF protein in cancer cells, thus influencing the tumor angiogenic activity and accelerating carcinogenesis such as bladder cancer, breast cancer, lung cancer, colorectal cancer, prostate cancer, ovarian cancer, and osteosarcoma (Li et al., 2010; Jaiswal et al., 2013; Kapahi et al., 2014; Deng et al., 2014; Lau et al., 2014; Chen et al., 2014; Wang et al., 2014). Jaiswal et al. (2013) reported that $V E G F$ polymorphisms may play a significant role in mediating bladder cancer. Kapahi et al. (2014) examined an Indian population and found that the $V E G F+936 \mathrm{C}>\mathrm{T}$ and $+405 \mathrm{C}>\mathrm{G}$ polymorphisms were associated with an increased risk of breast cancer. Lau et al. (2014) conducted a study in a Malaysian population and found that the VEGF gene polymorphism has a role in the development of colorectal cancer. These studies showed that $V E G F$ polymorphisms can influence the development of cancer, possibly by altering VEGF expression.

Several studies have examined the association between VEGF polymorphisms and RCC risk, but the results have been inconsistent (Kawai et al., 2007; Bruyère et al., 2010; Ajaz et al., 2011; Sáenz-López et al., 2013). Sáenz-López et al. (2013) conducted a case-control study to assess the role of 4 SNPs in $V E G F$ in the risk of RCC, and they found no significant association between them. Ajaz et al. (2011) found that the $V E G F-2578$ A-allele and A-carrier genotypes were associated with an increased risk of RCC. Kawai et al. (2007) suggested that the $-2578 \mathrm{C} / \mathrm{A}$ and $-1156 \mathrm{G} / \mathrm{A}$ polymorphisms may affect RCC progression or prognosis. Bruyère et al. (2010) found no significant association between the $+936 \mathrm{C} / \mathrm{T}$ polymorphism and risk of RCC. Our study showed that the $-2578 \mathrm{C} / \mathrm{A}$ and $+936 \mathrm{C} / \mathrm{T}$ polymorphisms in the VEGF gene may play a role in the development of RCC, which did not agree with the results of previous studies. The discrepancy in these results may be caused by differences in ethnicities, study design, and sample size.

Our study found that the $-2578 \mathrm{C} / \mathrm{A}$ and $+936 \mathrm{C} / \mathrm{T}$ polymorphisms interact with smoking habits. Mechanisms for the interaction between smoking habit and VEGF polymorphism may be caused by altering expression or protein activity (Conklin et al., 2002; Kanda and Watanabe, 2007). The $-2578 \mathrm{C} / \mathrm{A}$ and $+936 \mathrm{C} / \mathrm{T}$ polymorphisms were correlated with variation in $V E G F$ expression and protein production. Tobacco smoking can play a role in stimulating both angiogenesis and VEGF expression, and thus promote the procarcinogenic effect of angiogenesis (Wong et al., 2007). Therefore, tobacco smoking and VEGF activity can have multiple effects on the risk of RCC.

There were several limitations to our study. First, RCC cases and controls were selected from 1 hospital, and hospital-based cases may not be representative of other populations. However, the controls were a random sample from a pool of individuals who came to receive a health check-up, which may represent the general population. Third, the risk of RCC may be modified by many other genetic factors in the angiogenesis pathway, in addition to $V E G F$. Therefore, further studies including more subjects are needed to confirm the association between $V E G F$ gene polymorphisms and the risk of RCC.

In this case-control study, we found that the $-2578 \mathrm{C} / \mathrm{A}$ and $+936 \mathrm{C} / \mathrm{T}$ polymorphisms in the $V E G F$ gene may play a role in the etiology of RCC. Further large-sample studies are needed to confirm these associations. 


\section{REFERENCES}

Ajaz S, Khaliq S, Abid A, Hassan AS, et al. (2011). Association of a single-nucleotide polymorphism in the promoter region of the VEGF gene with the risk of renal cell carcinoma. Genet. Test. Mol. Biomarkers 15: 653-657.

Bellocco R, Pasquali E, Rota M, Bagnardi V, et al. (2012). Alcohol drinking and risk of renal cell carcinoma: results of a meta-analysis. Ann. Oncol. 23: 2235-2244.

Bergström A, Hsieh CC, Lindblad P, Lu CM, et al. (2001). Obesity and renal cell cancer: a quantitative review. Br. J. Cancer 85: 984-990.

Bjørge T, Tretli S and Engeland A (2004). Relation of height and body mass index to renal cell carcinoma in two million Norwegian men and women. Am. J. Epidemiol. 160: 1168-1176.

Bruyère F, Hovens CM, Marson MN, d'Arcier BF, et al. (2010). VEGF polymorphisms are associated with an increasing risk of developing renal cell carcinoma. J. Urol. 184: 1273-1278.

Cai C, Wang LH, Dong Q, Wu ZJ, et al. (2013). Association of CXCL12 and CXCR4 gene polymorphisms with the susceptibility and prognosis of renal cell carcinoma. Tissue Antigens 82: 165-170.

Chen GQ, Luo JB, Wang GZ, Ding JE (2014). Assessment of the associations between three VEGF polymorphisms and risk of prostate cancer. Tumour Biol. 35: 1875-1879.

Conklin BS, Zhao W, Zhong DS and Chen C (2002). Nicotine and cotinine up-regulate vascular endothelial growth factor expression in endothelial cells. Am. J. Pathol. 160: 413-418.

Deng ZC, Cao C, Yu YM, Ma HY, et al. (2014). Vascular endothelial growth factor -634G/C and vascular endothelial growth factor $-2578 \mathrm{C} / \mathrm{A}$ polymorphisms and lung cancer risk: a case-control study and meta-analysis. Tumour Biol. 35: 1805-1811.

Hunt JD, van der Hel OL, McMillan GP, Boffetta P, et al. (2005). Renal cell carcinoma in relation to cigarette smoking: meta-analysis of 24 studies. Int. J. Cancer 114: 101-108.

Jaiswal PK, Tripathi N, Shukla A and Mittal RD (2013). Association of single nucleotide polymorphisms in vascular endothelial growth factor gene with bladder cancer risk. Med. Oncol. 30: 509.

Jemal A, Siegel R, Ward E, Hao Y, et al. (2009). Cancer statistics, 2009. CA Cancer J. Clin. 59: 225-249.

Jia CY, Liu YJ, Cong XL, Ma YS, et al. (2014). Association of glutathione S-transferase M1, T1, and P1 polymorphisms with renal cell carcinoma: evidence from 11 studies. Tumour Biol. 35: 3867-3873.

Kanda Y and Watanabe Y (2007). Nicotine-induced vascular endothelial growth factor release via the EGFR-ERK pathway in rat vascular smooth muscle cells. Life Sci. 80: 1409-1414.

Kapahi R, Manjari M, Sudan M, Uppal MS, et al. (2014). Association of $+405 \mathrm{C}>\mathrm{G}$ and $+936 \mathrm{C}>\mathrm{T}$ polymorphisms of the vascular endothelial growth factor gene with sporadic breast cancer in North Indians. Asian Pac. J. Cancer Prev. 15: 257-263.

Kawai Y, Sakano S, Korenaga Y, Eguchi S, et al. (2007). Associations of single nucleotide polymorphisms in the vascular endothelial growth factor gene with the characteristics and prognosis of renal cell carcinomas. Eur. Urol. 52: 11471155.

Kushner EJ and Bautch VL (2013). Building blood vessels in development and disease. Curr. Opin. Hematol. 20: 231-236.

Lau TP, Roslani AC, Lian LH, Lee PC, et al. (2014). Association between EGF and VEGF functional polymorphisms and sporadic colorectal cancer in the Malaysian population. Genet. Mol. Res. 13: 5555-5561.

Li Y, Wang Y, Kang S, Wang N, et al. (2010). Association of vascular endothelial growth factor gene polymorphisms with susceptibility to epithelial ovarian cancer. Int. J. Gynecol. Cancer 20: 717-723.

Maeda A, Nakata M, Yasuda K, Yukawa T, et al. (2013). Influence of vascular endothelial growth factor single nucleotide polymorphisms on non-small cell lung cancer tumor angiogenesis. Oncol. Rep. 29: 39-44.

McLaughlin JK, Chow WH, Mandel JS, Mellemgaard A, et al. (1995). International renal-cell cancer study. VIII. Role of diuretics, other anti-hypertensive medications and hypertension. Int. J. Cancer 63: 216-221.

Motzer RJ, Hutson TE, Tomczak P, Michaelson MD, et al. (2007). Sunitinib versus interferon alfa in metastatic renal-cell carcinoma. N. Engl. J. Med. 356: 115-124.

Mu HJ, Zou J, Xie P, Xu ZQ, et al. (2014). Association of leptin receptor Lys109Arg and Gln223Arg polymorphisms with increased risk of clear cell renal cell carcinoma. Asian Pac. J. Cancer Prev. 15: 4211-4215.

Patard J-J, Pouessel D, Bensalah K and Culine S (2008). Targeted therapy in renal cell carcinoma. World J. Urol. 26: 135-140.

Roy H, Bhardwaj S and Yla-Herttuala S (2006). Biology of vascular endothelial growth factors. FEBS Lett. 580: 28792887.

Sáenz-López P, Vazquez F, Cozar JM, Carretero R, et al. (2013). VEGF polymorphisms are not associated with an increased risk of developing renal cell carcinoma in Spanish population. Hum. Immunol. 74: 98-103. 
Wang Z, Wen P, Luo X, Fang X, et al. (2014). Association of the vascular endothelial growth factor (VEGF) gene singlenucleotide polymorphisms with osteosarcoma susceptibility in a Chinese population. Tumour Biol. 35: 3605-3610.

Wong HP, Yu L, Lam EK, Tai EK, et al. (2007). Nicotine promotes colon tumor growth and angiogenesis through betaadrenergic activation. Toxicol. Sci. 97: 279-287.

Yang L, Parkin DM, Ferlay J, Li L, et al. (2005). Estimates of cancer incidence in China for 2000 and projections for 2005. Cancer Epidemiol. Biomarkers Prev. 14: 243-250.

Yang Y, Zhang X, Song D and Wei J (2014). Association between vascular endothelial growth factor gene polymorphisms and bladder cancer risk. Mol. Clin. Oncol. 2: 501-505.

Zhang S, Qian J, Cao Q, Li P, et al. (2014). A potentially functional polymorphism in the promoter region of miR-34b/c is associated with renal cell cancer risk in a Chinese population. Mutagenesis 29: 149-154.

Zhang Y, Li S, Xiao HQ, Hu ZX, et al. (2013). Vascular endothelial growth factor gene polymorphisms and renal cell carcinoma: A systematic review and meta-analysis. Oncol. Lett. 6: 1068-1078.

Zhong W, Wang X, Pan B and Su Z (2014). Association of vascular endothelial growth factor polymorphisms with clinical outcome of renal cell carcinoma patients. Tumour Biol. 35: 9839-45. 